\title{
BoerPE Goat Blood Profile as Indicators of Crossbreeding Resistance
}

\author{
Nurul Humaidah a ${ }^{*}$, Dedi Suryanto ${ }^{b}$, Inggit Kentjonowaty ${ }^{c}$ \\ ${ }^{a}$ Department of Reproduction and Animal Health, University of Islam Malang, Malang, Indonesia \\ ${ }^{b}$ Department of Animal Physiology, University of Islam Malang, Malang, Indonesia \\ c Department of Animal Production, University of Islam Malang, Malang, Indonesia \\ *email:annurul_humaidah@unisma.ac.id
}

\begin{tabular}{l}
\hline A R T I C L E I N F O \\
\hline Article history: \\
Received 06 Nopember 2020 \\
Revised 17 Nopember 2020 \\
Accepted 03 December 2020 \\
Available 13 Desember 2020 \\
\hline Keywords: \\
Profile \\
Blood \\
BoerPE \\
Crossbreeding \\
Resistance \\
\\
\hline IEEE style in citing this \\
article: \\
N. Humaidah, D. Suryanto \\
and I. Kentjonowaty, " \\
BoerPE Goat Blood Profile \\
as Indicators of \\
Crossbreeding Resistance," \\
Jurnal Ternak \\
Universitas Islam \\
Lamongan, vol. 6, no. 1, pp. \\
66 - 72, 2020.
\end{tabular}

\section{E I N F O}

Received 06 Nopember 2020

Revised 17 Nopember 2020

Accepted 03 December 2020

Keywords:

BoerPE

Crossbreeding

Resistance

\section{IEEE style in citing this}

article:

and I. Kentjonowaty, "

BoerPE Goat Blood Profile

as Indicators of

Crossbreeding Resistance,"

Universitas Islam

$66-72,2020$.

\section{A B S T R A C T}

Cases of clinical reproduction in crossbred cattle have been reported with the incidence of decreased reproductive performance. Crossbreeding resistance is usually followed by low immunity. Blood profile is one of the parameters that illustrate the immunity of livestocks. Goat crossbreeding resistance has never been studied. The purpose of this study was to analyze the crossbreeding resistance of the F1 BoerPE goat and her mothers by analyzing their blood profile. F1 BoerPE goat is the offspring of crossbreeding between Boer buck with PE goat. The research method was case study. The primary data were obtained from examination of blood profile and Physiological Status of F1 BoerPE goat and her mothers. The secondary data obtained from recording age and body weight. The blood profile data were analyzed by $t$ test. The observed blood profile indicators were neutrophils, monocytes and lymphocytes. The results showed that the physiological status of F1 BoerPE goat and her mothers was not significant. Nevertheless, the number of neutrophils, lymphocytes and monocytes was significantly different $(\mathrm{p}<0.01)$. The average $(\%)$ number of neutrophils, lymphocytes and monocytes of PE goats was $37.92 \pm 1.37 ; 51.85 \pm$ $1.4 ; 3.87 \pm 0.21$. while the average blood profile of F1 BoerPE was $46.16 \pm 2.1$; $58.06 \pm 3.4 ; 5.51 \pm 0.18$. The average number of neutrophils, lymphocytes and monocytes F1 BoerPE goat was higher compared to the parent. It is indicated that there were crossbreeding resistance of F1 BoerPE goat.

Faculty of Animal science - Lamongan Islamic Unal Ternak (Animal Science Journal)

\section{Introduction}

BoerPE goat is the result of crossing the Boer buck with the crossbreed Etawa doe (PE). Crossing rematings of livestock from different breed. The main purpose of crossing is to combine two or more different characters into one crossbreed. The result of crossing can have a higher or lower advantage (hybrid vigor) than the average ability of the parents [1].

The Hybrid Vigor desired from the BoerPE goat is the good growth inherited from the Boer buck and adaptable to various environmental conditions in Indonesia which inherits from the local PE doe. BoerPE goat has the potential for a high carcass yield and can be developed as a superior new breed in the future. BoerPE goats have an average birth weight of 30-40\% heavier than PE goats [2].

Research on the negative impact of crossbreeding or crossbreeding resistance in goats has yet to be carried out. There have been many studies of the cattle cross breeding impact on their calves but not in goats. The crossbred calves (F1) have a significant gain in body weight, but the F1 Crosbred produced from the crossbreeding results decrease their reproductive performance. This occurs especially if it is not balanced with adequate and quality feed. Reproduction performance is of course related to efficient reproduction. Bad reproduction performance includes increased of service per conception $(\mathrm{S} / \mathrm{C})$, decreased of conception rate $(\mathrm{CR})$, calf crop and long calving interval. In addition to decreased reproductive performance, milk production also decreases, this results in a high rate of calf mortality [3]. It was also reported that SIMPO (Simental PO) F3 cross breeding cattle has a bad 
reproductive performance i.e CR 39\%, SC 3.9 and Days Open 236 days. The reproductive performance of PO breeders is better i.e CR 80\%, SC 1,2, DO 158 days. Clinical reproduction cases in F3 also increased consecutively i.e Anestrus 68\%, Endometritis 31\%, Repeat Breeding 67\%, Persistent Corpus Luteum $16 \%$ compared to $\mathrm{PO}$ ie $38 \%, 8 \% 28 \%, 6 \%$ [4]. The reproductive performance is not different between Boer and F1 BoerPe [5] but there have been no studies on F2 and F3 BoerPE.

\section{State of the Art}

Cross breeding resistance is a condition in which the results of the cross offspring show poor production and reproductive performance [6]. This usually happens because the blood composition of imported parents should be more higher than local parent followed by poor maintenance management, especially from feeding [7]. Crossbreeding resistance only can be seen if there is recording of crossbreeding up to the $3^{\text {rd }}(\mathrm{F} 3)$ or $4^{\text {th }}(\mathrm{F} 4)$ generation. Cossbreeding resistance usually followed by low immunity defense [8]. A review of heartwater disease in goats showed that the prevalence of crossbred was higher (65\%) than local goats [9]. The blood profile, especially Leucocyte differentiation, can be an indicator of resistance for crossbreeding and immune defense [10].

Research on BoerPE goat blood profile as an indicator of cross breeding resistance has not been carried out. The objective of this research was to get the blood profile of the crossbred goats and to analyze it by comparing the blood profile of PE goats as a marker. Stress and reproductive status are known to have a profound effect on the hematological and biochemical profiles of small ruminants [11]. F1 crossbred goats with normal Leucocyte differentiation value indicate low crossbreeding resistance [12]. This F1 crossbred can be used as the chosen parent to produce the next generation. Obtaining a crossbred goat that has low crossbreeding resistance can be done without waiting for the results of F3 or F4 crossbred. Selected crossbreed offspring having low crossbreeding resistance can become prospective parents. Goats having a low crossbreeding resistance can be chosen as a new composite goat that produce a good production and reproduction.

\section{Method}

The research method was case study. The primary data were obtained from the results of blood profile examinations and measurement of the physiological status of goats. The secondary data were obtained from recording BoerPE goats including : age, birth weight, weaning weight, and body weight. The experimental livestock were the PE parent goat aged about 3.5-4 years with average body weight of $35-40 \mathrm{~kg}$ and F1 BoerPE aged about 1.5-1.7 years with average body weight of 29-35 kg. Each of them totaled 30 goats. Adaptation of goats to cages and feed was carried out for 7 days so that measurements of body weight and relative physiological status were not different. Physiological status measured were body temperature, respiration frequency and heart rate. The body temperature was measured by using a digital thermometer that was inserted into the rectum along one third of the thermodigital tube. Recording digital display after hearing the sound of the thermometer. Measurements were taken in duplo every morning, one hour after eating. Measurements were made three times. Measuring the frequency of respiration was done by counting the respiration out of the goats for 1 minute. To find out the breathing of goats could be done by bringing the back hand to the goats nose. The calculation of respiration were duplo. It used counter and stopwatch. It was repeated three times. The pulse was measured using a stethoscope. The stethoscope was taken to the left thoracic (chest) that is area near the heart to get loud heartbeat. This pulse measurement was carried out on standing goats position. The Heart rate counting was performed for 1 minute and was duplicated. The counting was repeated three times [10]. The feeding was done twice a day. In the morning, it was between 6:30 a.m. and 07:30 a.m. while in the afternoon it was 3:00 p.m. to 4:00 p.m. The feed was forage and concentrate. The provision of drinking water was ad libitum.

Blood samples were collected from jugular vein, afer two hours being fed. The jugular vein is the area of the upper third of the neck. This area was shaved to make it easier to draw blood. Before inserting a needle, disinfection was carried out. After that, the neck area was dammed so that the jugular veins appeared and then blood was drawn. Blood draw using a syringe measuring $5 \mathrm{ml} .2 \mathrm{ml}$ of blood was drawn and then inserted into the EDTA venoject tube. The venoject tube was put in a 
cold flask to be taken to the laboratory. Blood profile analysis was performed by using Humacount ${ }^{\circledR}$ 30TS (Hematology Analyzer). The blood profile measured was the differentiation of leukocyte i.e neutrophils, lymphocytes and monocytes. The data obtained were analyzed using the $t$ test to see the differences in the hematological profiles between PE and F1 BoerPE goats. The data were analyzed by using SPSS Software (version 16.0 for Windows). Physiological status data were analyzed by using descriptive method.

\section{Results and Discussion \\ Physiological Status}

The physiological status of livestock can describe the health status of livestock. Direct measurement physiological status of livestock includes respiration, heart rate, and rectal temperature. This parameter describes the physical, chemical and biological status of body cells related to the physiological processes that occur in the body [11]. Physiological status of PE goat with F1 BoerPE was in table 1.

Tabel 1. Physiological status of PE goat and Crossbred BoerPE

\begin{tabular}{|l|c|c|c|}
\hline \multicolumn{1}{|c|}{ Physiological status } & PE Goat & F1 BoerPE & Normal Rate [12] \\
\hline Temperature $\left({ }^{\circ} \mathrm{C}\right)$ & $39,50 \pm 0,32$ & $39,35 \pm 0,32$ & $38,5-40$ \\
\hline pulse $(\mathrm{x} /$ minutes $)$ & $127,15 \pm 0,75$ & $129,09 \pm 7,5$ & $70-135$ \\
\hline Respiration $(\mathrm{x} /$ minutes $)$ & $35,00 \pm 0,78$ & $41,00 \pm 1,09$ & $26-54$ \\
\hline
\end{tabular}

The results showed that the physiological status of the PE goats and F1 BoerPE was not different on average. Body temperature, pulse rate, and respiration of the PE goats and F1 BoerPE were still within normal ranges. It was because the body weight between the parent and the F1 BoerPE was not much different, that was in the range of $35 \mathrm{~kg}$. The physiological status of livestock describes the physiological processes associated with body metabolism. If it increases, it means that there are metabolic activities that require faster cell work processes [13]. This is linear with the body weight of the livestock. High body weight affects the value of pulse, respiration and body temperature. The pulse rate and respiration increase are influenced by the metabolic rate in the body. In F1 BoerPE, which inherits superior meat producing genes from Boer buck. It is suspected that the cell performance is work even harder so that it must be balanced with large oxygen demands. This will result in an increase in respiration frequency and temperature [14].

\section{Blood Profile}

Animal health status can be seen from the blood profile. The blood profile describes the health of the animal so that it can be used as a parameter to diagnose abnormalities that occur in the body [13]. Blood describes the physiological status of the body because it has an important function in regulating the body's physiology. Leukocytes are a blood profile that can describe the status of the immune system in the body. Leukocytes have fractions of the blood with different mechanisms of action but have one function, namely immunity [15]. The results showed that the blood leucocyte profile of PE doe was different from that of F1 BoerPE. The complete results of the blood profile are in table 2.

Table 2. Blood Profile of PE Goats and F1 crossbred BoerPE

\begin{tabular}{|c|c|c|c|}
\hline $\begin{array}{c}\text { Blood Profile } \\
\text { (\%) }\end{array}$ & PE Goats & F1 BoerPE & Note \\
\hline Neutrophils & $37,92 \pm 1,37$ & $46,16 \pm 2,1$ & Sn \\
\hline lymphocytes & $51,85 \pm 1,4$ & $58,06 \pm 3,4$ & Sn \\
\hline monocytes & $3,87 \pm 0,21$ & $5,51 \pm 0,18$ & Sn \\
\hline
\end{tabular}

Sn $=$ significantly $(\mathrm{p}<0,01)$

Leukocytes differentiation is one of the parameters that describes the animal's body defense. Leukocytes play a role in the body's defense system through differentiation of leukocytes. Leucocytes 
differentiate through various white blood cells with various types of neutrophil cells, lymphocytes, monocytes, eosonophils and basophils [10]. Neutrophils, lymphocytes and monocytes have functions with different defense mechanisms. The stress that occurs in livestock can be seen from the change in the number of leucocyte differences totally [16].

The profile of PE doe leukocytes was different from F1 BoerPE. BoerPE's F1 leucocyte profile had an average value higher than that of the PE goat. This indicated there was a crossbreed resistance of F1 BoerPE. Crossbreed resistance means that there are physiological efforts to respond to the results of crossbreeding [17]. Physiological efforts of crossbreeding resistance related to improving cell performance for increased productivity. The F1 BoerPE goat has the highest meat production genes of the Boer buck. These genes form patterns with the performance of cell metabolism such as Intramuscular Fat (IMF) and Sub Cutaneous Fat (SCF) accelerated quickly. The fast metabolic process results in an increase in livestock productivity [18]. This occurs due to the inherited trait of crossbreeding heterosis. One of the possibilities for heterosis is an increase in heterozygosity and a decrease in homozygosity. Livestock productivity can be increased through genetic variation due to cross breeding. Crossbreeding allows a combination of the superior traits of each parent [19].

The PE goats's Neutrophil levels were different from F1 BoerPE. The percentage of F1 BoerPE neutrophils was higher than that of PE parent. The average level of netrophils F1 BoerPE was $46.16 \%$, while the parent PE was $37.92 \%$. These different levels of neutrophils were still in the normal range. The normal neutrophils level of goats is $30-48 \%$ [20]. Neutrophils are the first line of defense in responding to immunity in the body. Neutrophils have the ability to engulf pathogenic organisms and cell debris by the process of phagocytosis [21]. Neutrophils will phagocytose these cells by chemotaxis movement. Neutrophils have an ability to kill foreign cells. It is because neutrophils have enzymes contained in granules. Neutrophilic granules are often referred to as lysosomes [22].

The lymphocyte level of F1 BoerPE goat was higher than that of the PE parent. The lymphocyte level of F1 BoerPE goat was $58.06 \%$, while the parent PE was $51.85 \%$. The relative level of lymphocytes is $50-70 \%$ [20]. The high levels of F1 BoerPE goat lymphocytes were thought to be from the increase in foreign bodies due to high cell work. Lymphocytes are white blood cells that produce antigens. This antigen arises due to the presence of macrophages that phagocytose foreign objects that appear in the body [23]. Lymphocytes are found in many lymphoid organs such as the spleen, thymus, tonsils and lymphoglands. Lymphocytes increase due to an increase in debris cells, foreign bodies and microorganisms in the body, especially certain viruses and bacteria [24]. Lymphocytosis is an increase in the number of lymphocytes in peripheral tissues. The causes are various factors, one of which is cell stress. Cell stress due to crossbreeding can increase the number of lymphocytes. The cell's stress response will be captured by lymphocytes. There are 2 response mechanisms in processing stress cells. It is through T lymphocytes and B lymphocytes. B lymphocytes play a role in the humoral immunity response in producing antibodies. These cells differentiate into plasma cells in response to stress cells. Meanwhile, T lymphocytes respond to stress cells through cellular immunity [25].

F1 BoerPE goats of monocyte level was higher than that of PE. Monocyte level of F1 BoerPE Goats was $5.51 \pm 0.18 \%$, while the parent PE was $3.87 \pm 0.21 \%$. The relative level of monocytes is $3-8 \%$ [23]. The increase in the number of monocytes can occur due to various factors. Stress factors, cell damage (necrosis), immune related diseases and red blood cell regeneration are factors that can increase the number of monocytes [21]. Crossbreeding with the aim of increasing productivity results in cell work harder. This results in the cells becoming stressed and if the body does not respond less, cell necrosis will occur. Monocytes work in cell necrosis through the immune system together with macrophages in phagocytosis of necrotic cells. Immunological response is maximized when there is synchronized contact between the surface of lymphocytes and monocytes [24].

Phagocytosis is the main mechanism of action of monocytes engulf microorganisms, dead cells, and foreign particles. The phagocytosis process occurs because monocytes in the bloodstream have the ability to diffuse in the walls of blood capillaries to join the connective tissue in the phagocytosis process. Phagocytosis of monocytes and macrophages work stronger than neutrophils. There are several receptor sites on the surface of the monocyte membrane thereby strengthening the 
immunoglobulin process and the formation of complement. Based on this, monocytes are classified as mononuclear phagocytes (reticuloendothelial system) [25].

The results of the study based on the leukocyte profile showed that the percentage of neutrophils, lymphocytes and monocytes of F1 BoerPE goat was greater than that of PE. This high percentage indicated crossbreed resistance in offspring goat. F1 BoerPE cells work harder to get higher production. The cell stress in F1 BoerPE resulted in an increase in the number of white blood cells. This is an indicator of crossbreed resistance and an indication of the adaptation of livestock to physiological stress [26]. Stress in livestock due to animal genetic make-up is immunosuppressive [27].

\section{Conclusions}

Physiological status between PE doe and F1 BoerPE goat was not different. The levels of physiological status for livestock are within the normal range even though the F1 BoerPE goat are higher. The blood profile of PE doe is different from F1 crossbreding BoerPE. The level of differentiation of F1 BoerPE leucocytes was higher than that of PE doe. Mean levels (\%) of Neutrophils, lymphocytes and monocytes of PE doe was $37.92 \pm 1.37,51.85 \pm 1.4$ and $3.87 \pm 0.21$ while F1 BoerPE was $46.16 \pm 2.1,58$, $06 \pm 3,4$ and $5.51 \pm 0.18$. Higher levels of F1 BoerPE leukocytes indicate cross resistance occurs in F1 BoerPE.

\section{Acknowledgment}

Author are grateful to the University of Islam Malang for supporting the grant for the research competition of the Islamic University of Malang (HIMA) 2020.

\section{References}

[1] D. D. Rahmat, "Strategi Pemuliaan Sapi Potong Yang Berkelanjutan Untuk Pemenuhan Kebutuhan Hewan Qurban (Sustainable Cattle Breeding Strategy for Eid Al-Adha Sacrifice)", JANHUS J Ilmu Peternak J Anim Husb Sci, vol. 2, no. 1, p. 19-25, 2018.

[2] K. Adhianto, S. Sulastri, M. D. I. Hamdani, D. Novriani dan L. Yuliani, "Performans Kambing Saburai Betina Di Wilayah Sumber Bibit Kabupaten Tanggamus Provinsi Lampung", J Ilmiah Ilmu-Ilmu Peternakan, vol.20, no.1, p. 9-16, 2017.

[3] K. Diwyanto and I. Inounu, "The Impact Of Crossbreeding In The Artificial Insemination Program On Reproductive Performance Of Beef Cattle", Wartazoa, vol. 19, no.2, p. 93-102, 2009.

[4] P. P. Putro, "Dampak Crossbreeding terhadap Reproduksi Induk Turunannya : Hasil Studi Klinis", Lokakarya Lustrum VIII Faultas Peternakan UGM, p.8, 2008.

[5] F. Parasmawati, Suyadi, dan S. Wahyuningsih, "Performan reproduksi pada persilangan Kambing Boer dan Peranakan Etawah (PE)', Jurnal Ilmu-Ilmu Peternakan, vol.23, no. 1, p. 11 17, 2013.

[6] N. Ibáñez-Escriche, E. Magallón, E. Gonzalez, J. F. Tejeda, and J. L. Noguera, “Genetic parameters and crossbreeding effects of fat deposition and fatty acid profiles in Iberian pig", J. Anim. Sci, vol. 94, pp. 28-37, 2016.

[7] S. Dash, A. K. Chakravarty, A. Singh, M. Upadhyay, M. Singh and S. Yousuf, "Effect of heat stress on reproductive performances of dairy cattle and buffaloes"A review. Vet world, vol. 9, no. 3, pp. 235-253, 2016.

[8] M. O. Adekunle, M. O. Abioja, J. A. Abiona, A. V. Jegede dan O. G. Sodipe, "Rectal temperature, 
heart rate, packed cell volume and differential white blood cell count of laying pullets to honey supplemented water during hot-dry season", Slovak J Anim Sci. vol 50, no. 1, 2017.

[9] C. E. Yunker, "Heartwater in sheep and goats: a review", Journal of Veterinary Research, vol. 63, pp. 159-170, 1996

[10] E. Rosita, I. G. Permana, T. Toharmat dan D. Despal, "Kondisi Fisiologis, Profil Darah Dan Status Mineral Pada Induk dan Anak Kambing Peranakan Etawah (PE) (Physiological Conditions, Blood Profile and Mineral Statues of Kid and Doe Etawah Crossbred)", Bul Ilmu Makanan Ternak", vol. 13, no. 1, 2015.

[11] S. Ghalem, N. Khebichat and K. Nekkaz, "The Physology of Animal Respiration: Study of Domestic Animal", Artic ID. 737271, vol. 8, 2012

[12] R. D. Frandson, "Anatomi Dan Fisiologi Ternak". Gadjah Mada University Press; 1993.

[13] S. A. Mohammed, M. A. Razzaque1, A. E. Omar, S. A, and W. M. Al-Gallaf, "Biochemical and hematological profile of different breeds of goat maintained under intensive production system", Afr. J. Biotechnol, Vol. 15. No. 24, pp. 1253-1257, 2016.

[14] C. S. O. Otoikhian, J. A. Orheruata, J. A. Imasuen and O. P. Akporhuarho, "Physiological response of local (West African Dwarf) and adapted Switzerland (White Bornu) goat breed to varied climatic conditions in South-South Nigeria", African J Gen Agric. vol. 5, no.1, p. 1-6, 2009.

[15] N. Koluman and I. Daskiran, "Effects of ventilation of the sheep house on heat stress, growth and thyroid hormones of lambs", Trop Anim Health Prod, vol 43, no. 6, p. 1123-1127, 2011.

[16] A. C. Guyton dan J. E, "Buku ajar fisiologi kedokteran" Jakarta EGC. Published online, edisi. 11, p. 81-85, 2007.

[17] M.H. Khalil, K.M. Mohamedb, A.M. Al-Saef, M.M. Zeitouna, M.F. El-Zarei, “Crossbreeding components for growth, carcass and meat composition traits in crossing Saudi Aradi with Damascus goats", Small Ruminant Research, no. 94, pp. 10-16, 2010.

[18] N. Ibáñez-Escriche, E. Magallón, E. Gonzalez, J. F. Tejeda, and J. L. Noguera, “Genetic parameters and crossbreeding effects of fat deposition and fatty acid profiles in Iberian pig", J. Anim. Sci, vol. 94, pp. 28-37, 2016

[19] J. P. C. Greyling, "Reproduction traits in the Boer goat doe", Small Rumin Res, vol. 36, no. 2, p. 171-177, 2000.

[20] K. S. Latimer, "Duncan and Prasse's Veterinary Laboratory Medicine: Clinical Pathology", John Wiley \& Sons, 2011.

[21] W. L. Lee, R. E. Harrison and S. Grinstein, "Phagocytosis by neutrophils", Microbes Infect. vol. 5, no. 14, p. 1299-1306, 2003.

[22] T. P. Colville, J. M, and J. M. Bassert, "Clinical Anatomy and Physiology for Veterinary Technicians", Mosby Elsevier, 2008.

[23] I. R. Tizard, "Type I hypersensitivity. Veterinary Immunology: an introduction" Published online 2000.

[24] K. E. Mate, J. M. Buist and J. A. Duckworth, "Expression in Escherichia coli and immunological characterization of three zona pellucida proteins (ZP1, ZP2, and ZP3) from a marsupial, the brushtail possum (Trichosurus vulpecula)", Mol Reprod Dev Inc Gamete Res, vol. 64, no. 2, pp. 136-143, 2003.

[25] D. J. Weiss and K. J, Wardrop, "Schalm's Veterinary Hematology", John Wiley \& Sons, 2011. 
[26] S. A. Mohammed, M. A. Razzaque, A.E. Omar, S. Albert and W. M. Al-Gallaf, "Biochemical and hematological profile of different breeds of goat maintained under intensive production system", African J Biotechnol, vol. 15, no. 24, pp. 1253-1257, 2016.

[27] P. U. Aikhuomobhogbe and A. M. Orheruata, "Haematological and blood biochemical indices of West African dwarf goats vaccinated against Pestes des petit ruminants (PPR)", African J Biotechnol, vol. 5, no. 9, 2006. 